\title{
Link between exposure of fish (Solea solea) to PAHs and metabolites: Application to the "Erika" oil spill
}

\author{
Hélène Budzinski ${ }^{1, a}$, Olivier Mazéas ${ }^{1,2}$, Jacek Tronczynski², Yves Désaunay ${ }^{3}$, Gilles Bocquené2 \\ and Guy Claireaux ${ }^{4}$ \\ ${ }^{1}$ Laboratoire de Physico- et Toxico-Chimie des Systèmes Naturels, UMR 5472 CNRS, Université Bordeaux 1, 351 cours de la Libération, \\ 33405 Talence, France \\ 2 IFREMER, DEL/PC, Centre de Nantes, rue de l'Ile d'Yeu, BP 21105, 44311 Nantes Cedex 3, France \\ 3 IFREMER, Laboratoire d'Ecologie Halieutique, Centre de Nantes, rue de l'Ile d'Yeu, BP 21105, 44311 Nantes Cedex 3, France \\ 4 CREMA, Place du Séminaire, BP 5, 17137 L'Houmeau, France
}

Received 6 January 2004; Accepted 9 September 2004

\begin{abstract}
An analytical method consisting in enzymatic deconjugation, solid phase extraction and purification, and gas chromatography/mass spectrometry analysis after derivatization was used in this study to quantify Polycyclic Aromatic Hydrocarbon (PAH) metabolites in the bile of fish. The method has been applied in a laboratory experiment studying the fate of pyrene in basin containing soles. This study has allowed the identification of 1-hydroxypyrene as the single metabolite in bile after enzymatic deconjugation. In a second time, 1-hydroxypyrene has been used as a biomarker of exposure in the case of the "Erika" oil spill. This biomonitoring was successful in demonstrating the exposure of juvenile soles to PAHs present in the "Erika" fuel oil.
\end{abstract}

Key words: PAH metabolites / Fish / Gas chromatography-mass spectrometry

\begin{abstract}
Résumé - Lien entre l'exposition de la sole (Solea solea) aux HAP et leurs métabolites : application à la marée noire de l'«Erika ». Dans cette étude, a été utilisée une méthode analytique, consistant en différentes étapes de déconjugaison enzymatique, d'extraction et de purification de la phase solide, et enfin d'analyse par chromatographie en phase gazeuse/spectrométrie de masse, après dérivation, pour quantifier les métabolites d'hydrocarbures aromatiques polycycliques (HAP) présents dans la bile de poisson. La méthode a été appliquée expérimentalement à l'étude du devenir du pyrène chez des soles maintenues en bassins. Cette étude a permis l'identification du 1-hydroxypyrène comme unique métabolite de la bile après déconjugaison enzymatique. Dans un second temps, le 1-hydroxypyrène a été utilisé chez la sole comme biomarqueur de l'exposition dans le cas de la marée noire de l'«Erika». Ce bio-suivi a démontré l'exposition des juvéniles de soles aux HAP présents dans le fioul de l'«Erika».
\end{abstract}

\section{Introduction}

The 12th of December 1999, the Erika oil tanker broke in two, close to the Atlantic coast of France. Consecutively to its sinking, around $20000 \mathrm{t}$ of fuel oil were spilled into the sea. On the 24th of December, the first slicks reached the coast. The Erika oil spill affected the coast-line from the South headland of Brittany to the North of Oléron Island. This area is of special importance considering fish as it shelters some of the largest nurseries of the French Atlantic coast.

Polycyclic aromatic hydrocarbons (PAHs) are important constituents of fuel oil in terms of quantity (Tissot and Welte 1978; Neff 1979; Boehm et al. 2001) and toxicity toward marine species (Moore et al. 1989; Baumann 1989; De Flora et al. 1991). Because of extensive metabolism of PAHs by fish

\footnotetext{
a Corresponding author: h.budzinski@lptc.u-bordeaux 1.fr
}

(Varanasi et al. 1989), metabolite quantification is more appropriate than $\mathrm{PAH}$ tissue content determination, when evaluating PAH exposure (Krahn et al. 1984, 1986a,b; McDonald et al. 1992; van der Oost 2003; Meador 2003). Metabolite concentrations are usually determined semi-quantitatively as global fluorescent aromatic compound equivalents (FACs) in the bile of fish (Krahn et al. 1984, 1986a; Ariese et al. 1993; Lin et al. 1996; Beyer et al. 1996; Aas et al. 2000). In order to evaluate the potential exposure of fish from nurseries within the area affected by the Erika fuel oil, an analytical method has been developed to determine individual PAH metabolite concentrations quantitatively in fish bile. This method has been applied to monitor the fate of pyrene (as a model compound representative of PAHs) in soles exposed to waterborne pyrene in basin. Then, the major metabolite of pyrene, 1-hydroxypyrene, previously demonstrated to be a predominant metabolite in fish bile 
(Krahn et al. 1987; Ariese et al. 1993), has been monitored in the bile of fish captured in a nursery site from the Atlantic coast of France on five occasions between February 2000 and September 2002.

\section{Material and methods}

\subsection{Chemicals}

1-hydroxypyrene (OHPyr) was purchased from Lancaster (Strasbourg, France), and 1-hydroxypyrene-d9 and phenanthrene-d10 from Cambridge Isotope Laboratories (Andover, MA, USA).

Various solvents were used. Methanol Lichrosolv was obtained from VWR (Strasbourg, France). Ultra Resi-Analysed methylene chloride (Mallinckrodt Baker) was purchased from Atlantic Labo (Eysines, France), Multisolvent ethyl acetate and ethanol (Scharlau) were provided by ICS Nationale (Belin Beliet, France) and sterilized water for injection was purchased from laboratory Aguettant (Lyon, France).

Acetic acid 100\% Normapur was provided by VWR (Strasbourg, France), sodium acetate trihydrate 99\% and $\beta$-glucuronidase-aryl-sulfatase mixture, 100000 and 7500 units $\mathrm{ml}^{-1}$ respectively, by Sigma-Aldrich (Saint Quentin Falavier, France). 2-mercaptoethanol and bis(trimethylsylil)trifluoroacetamide (BSTFA) were purchased from Acros organics (Noisy-Le-Grand, France).

The different steps of the protocol are: enzymatic deconjugation, solid phase extraction, purification, and analysis (Fig. 1).

\subsection{1-hydroxypyrene analysis}

Bile samples $(100 \mu \mathrm{l})$ were treated with $20 \mu \mathrm{l}$ of $\beta$-glucuronidase - aryl-sulfatase mixture (Sigma-Aldrich, Saint Quentin Falavier, France), 100000 et 7500 units $\mathrm{ml}^{-1}$ respectively, for enzymatic deconjugation. To this purpose, the bile samples were buffered to $\mathrm{pH} 5$ (acetate buffer constituted of sodium acetate and acetic acid in water). $20 \mu \mathrm{l}$ of 2-mercaptoethanol, used as an antioxidant, and the internal standard (1-hydroxypyrene-d9 (OHPyrd9)) were subsequently added to the samples. They were then placed in an oven at $37^{\circ} \mathrm{C}$ during $20 \mathrm{~h}$.

After ultra-sonication and centrifugation ( $5 \mathrm{~min}, 5000 \mathrm{rpm}$, $18{ }^{\circ} \mathrm{C}$ ), supernatants were loaded on Bakerbond $\mathrm{C}_{18}$ cartridges (Atlantic Labo, Eysines, France) previously preconditioned with $2 \mathrm{ml}$ of methanol and $4 \mathrm{ml}$ of water. Cartridges were washed with $2 \mathrm{ml}$ of water and $2 \mathrm{ml}$ water/methanol $(70: 30, v / v)$. Water traces were then removed by freeze-drying the cartridges. Freeze-drying was performed because of the possible loss of low molecular weight compounds during nitrogen stream drying at room temperature. Metabolites were then eluted with $6 \mathrm{ml}$ of methanol. Extracts were evaporated to dryness under a gentle nitrogen stream and re-dissolved in methylene chloride.

Supelclean LC-NH$H_{2}$ cartridges from Supelco (Saint Quentin Falavier, France) were then used for purification. Before loading the sample, the cartridge was first preconditioned

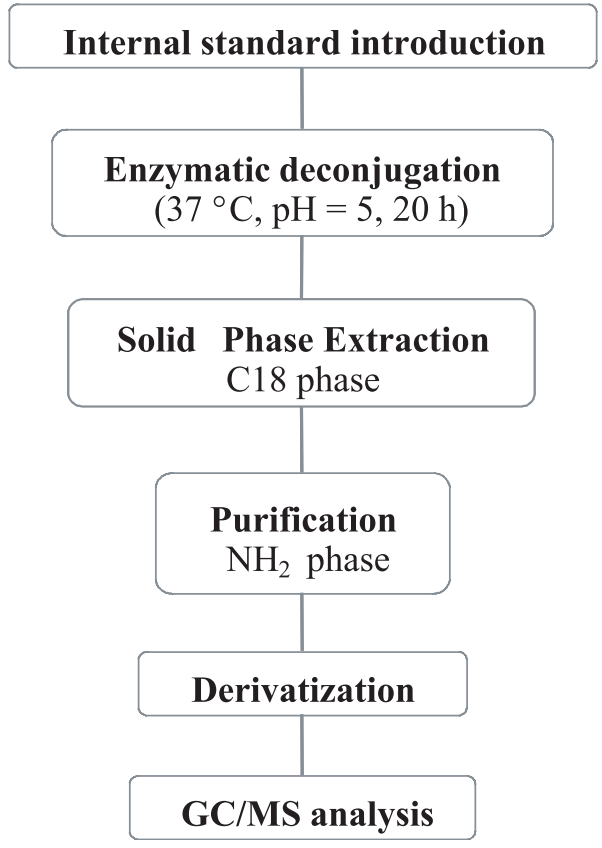

Fig. 1. Analytical protocol for the quantification of the studied PAH metabolites.

with $3 \mathrm{ml}$ methanol/methylene chloride (20:80, v/v). The selective elution of metabolites was obtained using $6 \mathrm{ml}$ of the mixture of solvents previously used. The final extract was evaporated to dryness under a gentle nitrogen stream and redissolved in methylene chloride.

After derivatization with BSTFA (30 min, $65{ }^{\circ} \mathrm{C}$ ), phenanthrene-d10 (Pd10) was added to the samples for recovery determination and analyses were performed by GC/MS using single ion monitoring mode (SIM; m/z = 188 ( $\mathrm{Pd} 10)$, 290 (OHPyr), 299 (OHPyrd9)) (automated PTV pulsed splitless injection (25 psi, $1.5 \mathrm{~min}$ ); purge delay: $1.5 \mathrm{~min}$ and purge flow: $60 \mathrm{ml} \mathrm{min}^{-1}$; injector temperature: $250{ }^{\circ} \mathrm{C}$; interface temperature: $280{ }^{\circ} \mathrm{C}$; oven temperature: from $70{ }^{\circ} \mathrm{C}$ (2 min) to $180{ }^{\circ} \mathrm{C}(1 \mathrm{~min})$ at $5{ }^{\circ} \mathrm{C} \mathrm{min}-1$ and from $180{ }^{\circ} \mathrm{C}$ to $290{ }^{\circ} \mathrm{C}(1 \mathrm{~min})$ at $10{ }^{\circ} \mathrm{C} \mathrm{min}^{-1}$, electron impact: $70 \mathrm{eV}$; voltage: $2000 \mathrm{~V}$; source temperature: $150{ }^{\circ} \mathrm{C} ; 1.53 \mathrm{scan} \mathrm{s}^{-1}$; dwell time: $50 \mathrm{~ms}$ ). Analyses were performed with a gas chromatograph Agilent Technologies (GC 6890A) equipped with a mass selective detector MSD 5973N. The column was a HP5/MS $(30 \mathrm{~m} \times 0.25 \mathrm{~mm} \times 0.25 \mu \mathrm{m}$; phase: $5 \%$ diphenyl-, $95 \%$ dimethyl-siloxane) and the carrier gas used was helium 6.0 provided by Linde (Toulouse, France). A mixture constituted of 1-hydroxypyrene and 1-hydroxypyrene-d9 was injected at the beginning and at the end of each GC/MS sequence for response factor determination and a manipulation blank was performed together with samples to control potential contamination (an example of a real sample chromatogram is presented Fig. 2). The glassware was washed with detergents and heated $6 \mathrm{~h}$ at $450^{\circ} \mathrm{C}$ before use.

\subsection{PAH analysis}

For the determination of PAHs in aqueous phase, water was first passed through a $0.7 \mu \mathrm{m}$ GFF filter (VWR, 


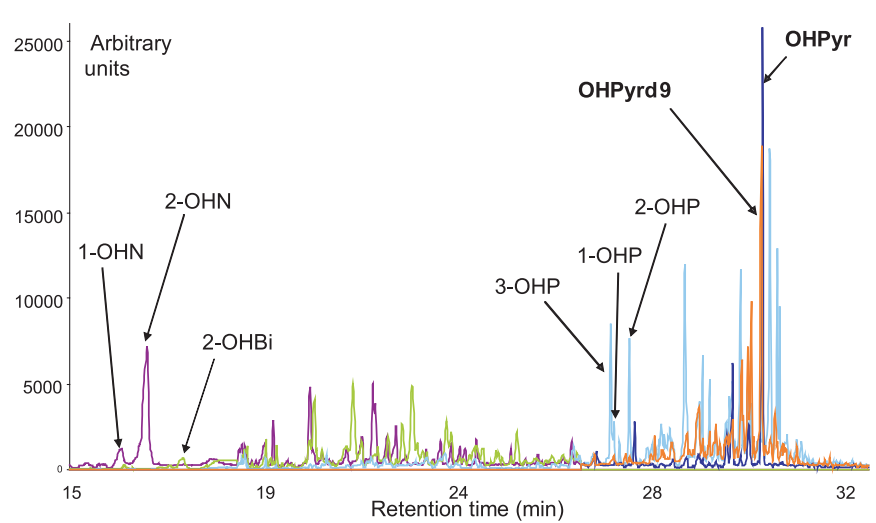

Fig. 2. GC/MS chromatogram (SIM mode) as an example of bile analysis for PAH metabolite determination. (OHN = hydroxynaphthalene, OHBi = hydroxy-biphenyl, OHP = hydroxyphenanthrene, OHPyr = hydroxy-pyrene)

Strasbourg, France) to separate dissolved PAHs from PAHs adsorbed on particulate matter.

PAHs were extracted from freeze-dried solid matrices (sediment, particulates, liver, muscle) by micro-wave extraction with methylene chloride followed by filtration on clean glass cotton (Budzinski et al. 1999).

Dissolved PAHs were extracted by passing water samples through an octadecyl speedisk (Baker, Atlantic Labo, Eysines, France) on which PAHs are retained. Analytes were then recovered by successive elutions with methylene chloride and methylene chloride/ethyle acetate $(1: 1, \mathrm{v} / \mathrm{v})$.

Extracts of the different matrices were then purified on alumina $\left(\mathrm{Al}_{2} \mathrm{O}_{3}\right)$ and silica $\left(\mathrm{SiO}_{2}\right)$ columns and analysed by GC/MS using single ion monitoring mode (SIM; based on molecular ions) (Budzinski et al. 1999). PAHs were quantified by internal standard quantification using perdeuterated PAHs (Baumard and Budzinski 1997).

The glassware was washed with detergents and heated $6 \mathrm{~h}$ at $450{ }^{\circ} \mathrm{C}$ before use.

\subsection{Laboratory study design}

Soles (Solea solea) were exposed to waterborne pyrene in October 2002. To this purpose, two $500 \mathrm{~L}$ basins, placed outdoors, covered with a polyethylene film and containing each one cleaned sand, were filled with $100 \mathrm{~L}$ of seawater. 36 fish were introduced into each one and were not fed during the experiment. In one of the basins, a single dose of $100 \mu \mathrm{g}$ of pyrene dissolved in $1 \mathrm{ml}$ of ethanol was added at T0 (start of the experiment). The other basin was used as a control. The contamination period lasted 7 days followed by a decontamination period (Td) of 7 days in clean basins supplied with open seawater circuit. Water temperature varied from 8.5 to $17.5^{\circ} \mathrm{C}$ and salinity from $33 \%$ to $35 \%$ during the experiment and depending on the hour of the day. The water was slightly oxygenated during the experiment.

Water was sampled for PAH quantification at T0 and after 3 days (T3) and 7 days (T7) for the control basin (duplicates of $500 \mathrm{ml}$ ). Water was sampled two hours after the
Table 1. Sampling framework of the laboratory experiment.

\begin{tabular}{cccc}
\hline \multirow{2}{*}{ Basin } & \multicolumn{3}{c}{ Sampling schedule } \\
& Water & Sand & Bile, liver, muscle \\
\hline Control & T0, T3, T7 & T1, T3, T7 & T1, T3, T7, Td \\
Pyrene & H2, T3, T7 & T1, T3, T7 & T1, T3, T7, Td \\
\hline
\end{tabular}

Tn time in days; Hn time in hours. Td: decontamination period of 7 days.

contamination (H2) and after 3 days and 7 days for the pyrene contaminated basin (duplicates of $100 \mathrm{ml}$ ).

Sand, liver and muscles were also monitored for PAH accumulation meanwhile bile was used for PAH metabolite content determination following the sampling framework presented in Table 1. When it was possible (taken into consideration the amount of bile), bile metabolite determination was undertaken in triplicate. The nine fish collected at each sampling time were quite heterogeneous. Two groups were thus distinguished based on their length. Only one of the two groups $(23 \pm 2 \mathrm{~cm})$ was analyzed. Analyses of biological matrices were led on pooled samples. Description of the analyzed fish is summarized in Table 2.

\subsection{Erika oil spill sample collection}

Soles were collected off the Loire River mouth (5-30 m depth), which was particularly impacted by Erika fuel, at five occasions following the Erika oil tanker wreckage. Age group 1 fish were captured at each sampling time, i.e. February, July and September 2000, September 2001 and 2002. They were dissected on boat just after capture and the organs were pooled before PAH or metabolite analyses (respectively muscle and liver for PAH determination and bile for metabolite determination).

Age group 1 corresponds to soles approximately starting their benthic juvenile development phase in May of the year preceding their capture. In this way, one can establish that fish collected during the first three campaigns belong to the same laying period, that they were born before the oil spill and that they lived through it. Fish collected in September 2001 were born a few months after the oil spill. Description of the pooled fish is summarized in Table 3.

\section{Results}

\subsection{Laboratory study}

Dissolved pyrene concentration shows a maximum two hours after contamination $\left(367 \pm 14 \mathrm{ng} \mathrm{L}^{-1}, n=3\right)$. The concentration at day $3\left(9.6 \pm 0.9 \mathrm{ng} \mathrm{L}^{-1}, n=3\right)$ and day 7 $\left(5.2 \pm 0.6 \mathrm{ng} \mathrm{L}^{-1}, n=3\right)$ shows a strong decrease after three days and a weaker one afterwards. However, this concentration does not return to T0 level $\left(0.6 \pm 0.2 \mathrm{ng} \mathrm{L}^{-1}, n=3\right)$. Quantification of pyrene in sediments or particulates does not show any adsorption phenomena to this material at any time of the 
Table 2. Description of the analysed pools in the laboratory experiment.

\begin{tabular}{ccccc}
\hline Sampling time & Exposure & $\begin{array}{c}\text { Number of fish } \\
\text { in the pool }\end{array}$ & Length (cm) & $\begin{array}{c}\text { Number of replicates for } \\
\text { bile analyses }\end{array}$ \\
\hline T0 & control & 3 & $23 \pm 1$ & 2 \\
control & pyrene & 3 & $25 \pm 1$ & 3 \\
& control & 3 & $21 \pm 1$ & 3 \\
T3 & pyrene & 3 & $26 \pm 2$ & 3 \\
& control & 3 & $23 \pm 1$ & 3 \\
T7 & pyrene & 3 & $25 \pm 1$ & 3 \\
& control & 2 & 24 & 1 \\
Td & pyrene & 1 & $20 \pm 1$ & 1 \\
\hline
\end{tabular}

Table 3. Sampling framework and description of the analysed pools from fish sampled off the Loire Estuary.

\begin{tabular}{cccc}
\hline Campaign date & $\begin{array}{c}\text { Number of } \\
\text { fish } \\
\text { in the pool }\end{array}$ & Length (cm) & $\begin{array}{c}\text { Number of replicates } \\
\text { for bile analyses }\end{array}$ \\
\hline Feb. 2000 & 10 & $14 \pm 1$ & 1 \\
July 2000 & 10 & $15-20$ & 1 \\
Sept. 2000 & 10 & $21 \pm 1$ & 2 \\
Sept. 2001 & 10 & $21 \pm 2$ & 1 \\
Sept. 2002 & 10 & 21 & 2 \\
\hline
\end{tabular}

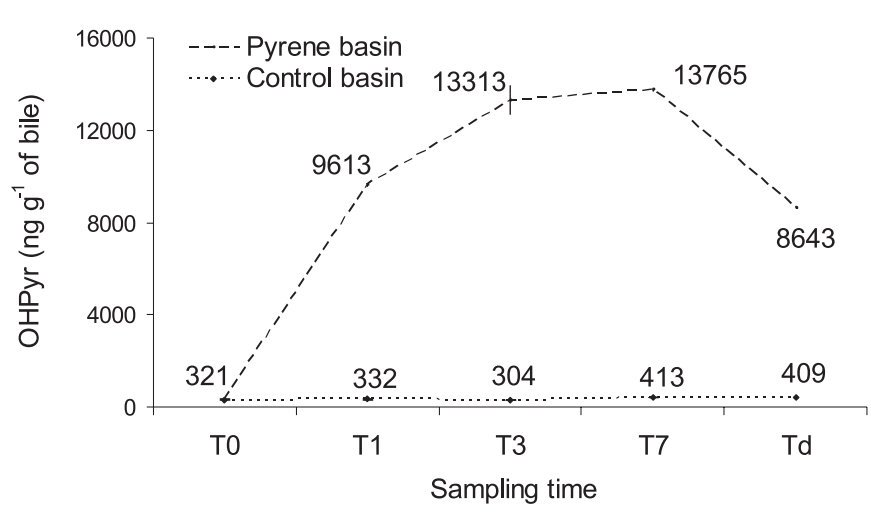

Fig. 3. 1-hydroxypyrene (OHPyr) concentration in the bile of soles from the control and pyrene exposures of the experimental study. T0, T1, T3, T7 for sampling days, respectively $0,1,3$ and 7 days of exposure; Td for sampling after depuration of 7 days.

experiment. Concerning the fate of pyrene in fish, no bioaccumulation is either detected in liver or muscle. In bile samples, a single metabolite, 1-hydroxypyrene is detected after enzymatic deconjugation compared to control bile. After one day, a large increase of 1-hydroxypyrene concentration is observed (Fig. 3). From T1 to T7, a smaller increase is observed. After the decontamination period, the level of 1-hydroxypyrene decreases under the level of T1 but does not return to T0 level. No dissolved metabolite is detected in water.

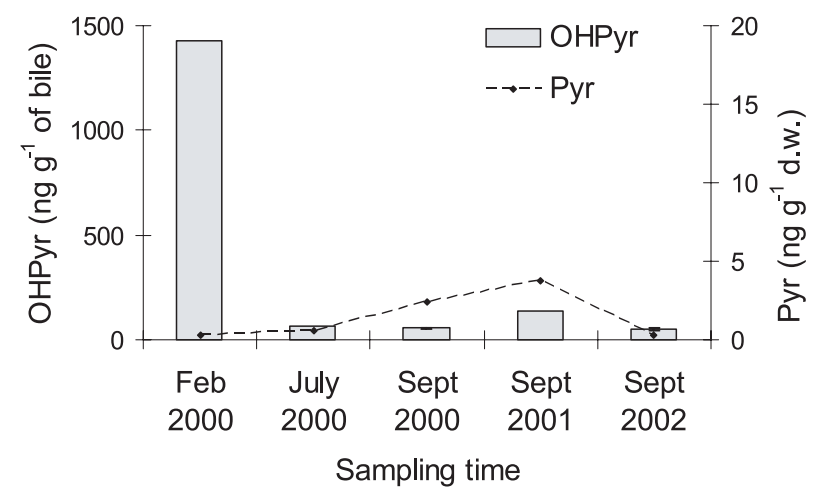

Fig. 4. 1-hydroxypyrene (OHPyr) concentration in the bile and pyrene (Pyr) concentration in the muscles of soles sampled from the Loire Mouth. (d.w.: dry weight basis).

\subsection{Application to the Erika oil spill}

In contrast to pyrene concentrations in muscle, 1-hydroxypyrene concentrations in the bile of fish collected from the Loire Estuary in February 2000 show greater levels than in the bile of the fish collected during the following campaigns (Fig. 4).

\section{Discussion}

Concerning the laboratory experiment, 1-hydroxypyrene is the only metabolite detected in the bile indicating that pyrene is eliminated as glucuronide or sulphate conjugates, or less probably unconjugated, into the gall bladder under the form 
of a single isomer. This result is in good agreement with a previous study concerning the flounder, Platichthys flesus (Luthe et al. 2002).

Furthermore, an important difference is observed between theoretical nominal $\left(1 \mu \mathrm{g} \mathrm{L}^{-1}\right)$ and actual level $(367 \pm$ $14 \mathrm{ng} \mathrm{L}^{-1}, n=3$ ) of dissolved pyrene in water two hours after contamination. Taking into account the fact that no increase of pyrene concentration is observed in particulate matter and sediment at this time, this difference can be attributed to adsorption on the basin surface, photochemical degradation or, to a smaller extend, to fish absorption. This result underlies the importance of leading actual measures of contamination in microcosm or mesocosm experiments. The large decrease of dissolved pyrene concentration observed after 3 days can only be attributed to the same phenomena because of the unexpected non-adsorption of pyrene on particulates and sediment. The absence of bioaccumulation of pyrene in the liver and muscle of fish can be explained by the large increase of 1-hydroxypyrene after no more than one day. These results indicate that the pyrene absorbed by fish is efficiently metabolized. This can be explained by the low level of contamination chosen for this experiment. The weaker increase observed at days 3 and 7 can be correlated with the weaker level of dissolved pyrene in water.

At the end of the decontamination period, the level of 1-hydroxypyrene decreases under the level of T1 but does not return to T0 level. This could be due to the non-feeding of fish which prevents from normal elimination of the bile into the intestine.

Concerning the field study, the low levels of pyrene in muscle of fish during the five campaigns (between 10 and $30 \mathrm{ng} \mathrm{g}^{-1}$ of dry tissue for the sum of 12 of the 16 PAHs of the US-EPA: phenanthrene, anthracene, fluoranthene, pyrene, benz(a)anthracene, chrysene (+triphenyle), benzo(b)fluoranthene, benzo(k)fluoranthene (+benzo(j)fluoranthene), benzo(a)pyrene, dibenz(a,h)anthracene (+dibenz(a,c)anthracene), benzo(g,h,i)perylene and indeno( 1,2 , 3 -cd)pyrene) put in evidence the unfeasibility of using PAH quantification for pollution diagnostic in the case of fish. On the contrary, the high level of 1-hydroxypyrene observed two months after the Erika sinking demonstrates the large exposure of juvenile soles to the Erika fuel oil and suggests a potential impact of the oil spill on French Atlantic sole nurseries. This is in good agreement with previous studies showing high levels of PAH metabolites in the bile of fish collected after other oil spill events (Krahn et al. 1986b, 1992, 1993; Jewett et al. 2002; Huggett et al. 2003; Marty et al. 2003). The low levels measured in fish from the same generation (which have lived through the oil spill) 4 months later indicates the excretion of the biliary metabolites measured in February and the rapid decrease of the pollution. It could be considered that the system returns to a sort of background level of 1-hydroxypyrene bile content around $50 \mathrm{ng} \mathrm{g}^{-1}$ of bile. Nevertheless, due to unknown levels of metabolites before the oil spill, it is impossible to insure that the system has returned to its initial state and to conclude definitively on the non-persistent character of the Erika oil spill.

\section{Conclusion}

The study of pyrene transformation by soles has allowed to identify 1-hydroxypyrene as the single metabolite of pyrene in bile after enzymatic deconjugation. In addition, this study has demonstrated the efficiency of the sole to rapidly metabolize pyrene. Finally, results of field campaigns led in the nursery of the Loire Estuary after the Erika oil spill have shown the interest of PAH metabolite monitoring to evaluate the exposure of fish to PAHs. This biomonitoring has allowed to put in evidence the exposure of juvenile soles to PAHs contained in Erika fuel oil.

Acknowledgements. The French Ministry "Écologie et Développement Durable" is acknowledged for financial support through the Erika program.

\section{References}

Aas E., Beyer J., Goksøyr A., 2000, Fixed wavelength fluorescence (FF) of bile as a monitoring tool for polyaromatic hydrocarbon exposure in fish: an evaluation of compound specificity, inner filter effect and signa interpretation. Biomarkers 5, 9-23.

Ariese F., Kok S.J., Verkaik M., Gooijer C., Velthorst N.H., Hofstraat J.W., 1993, Synchronous fluorescence spectrometry of fish bile: A rapid screening method for the biomonitoring of PAH exposure. Aquat. Toxicol. 26, 273-286.

Baumann P.C., 1989, PAH, metabolites, and neoplasia in feral fish populations. In: Varanasi U. (Ed.), Metabolism of PAH in the Aquatic Environment. CRC, Boca Raton, FL, USA, pp. 269-290.

Beyer J., Sandvik M., Hylland K., Fjeld E., Egaas E., Aas E., Skåre J.U., Goksøyr A., 1996, Contaminant accumulation and biomarker responses in flounder (Platichthys flesus L.) and Atlantic cod (Gadus morhua L.) exposed by caging to polluted sediments in Sørfjorden, Norway. Aquat. Toxicol. 36, 75-98.

Boehm P.D., Page D.S., Burns W.A., Bence A.E., Mankiewicz P.J., Brown J.S., 2001, Resolving the origin of the petrogenic hydrocarbon background in Prince William Sound, Alaska. Environ. Sci. Technol. 35, 471-479.

Budzinski H., Letellier M., Garrigues P., Le Menach K., 1999, Optimisation of the microwave-assisted extraction in open cell of PAHs from soils and sediments - Study of moisture effect. J. Chromatogr. A. 837, 187-200.

De Flora S., Bagnasco M., Zanacchi P., 1991, Genotoxic, carcinogenic and teratogenic hazards in the marine environment, with special reference to the Mediterranean Sea. Mutation Res. 258, 285-320.

Huggett R.J., Stegeman J.J., Page D.S., Parker K.R., Woodin B., Brown J.S., 2003, Biomarkers in Fish from Prince William Sound and the Gulf of Alaska: 1999-2000. Environ. Sci. Technol. 37, 4043-4051.

Jewett J.C., Dean T.A., Woodin B.R., Hoberg M.K., Stegeman J.J., 2002, Exposure to hydrocarbons 10 years after the Exxon Valdez. oil spill: evidence from cytochrome P4501A expression and biliary FACs in nearshore demersal fishes. Mar. Environ. Res. 54, 21-48.

Krahn M.M., Myers M., Burrows D.G., Malins D.C., 1984, Determination of metabolites of xenobiotics in bile of fish from polluted waterways. Xenobiotica 14, 633-646. 
Krahn M.M., Rhodes L.D., Myers M.S., Moore L.K., MacLeod W.D., Malins D.C., 1986a, Associations between metabolites of aromatic compounds in bile and the occurrence of hepatic lesions in English sole (Parophrys vetulus) from Puget Sound, Washington. Arch. Environ. Contam. Toxicol. 15, 61-67.

Krahn M.M., Kittle L.J., McLeod W.D., 1986b, Evidence for exposure of fish to oil spilled into the Columbia River. Mar. Environ. Res. 20, 291-298.

Krahn M.M., Burrows D.G., MacLeod W.D., Malins D.C., 1987, Determination of individual metabolites of aromatic compounds in hydrolysed bile of English sole (Parophrys vetulus) from Puget Sound, Washington. Arch. Environ. Contam. Toxicol. 16, 511-522.

Krahn M.M., Burrows D.G., Ylitalo G.M., Brown D.W., Wigren C.A., Collier T.K., Chan S.-L., Varanasi U., 1992, Mass spectrometric analysis for aromatic compounds in bile of fish sampled after the Exxon Valdez oil spill. Environ. Sci. Technol. 26, 116-126.

Krahn M.M., Ylitalo G.M., Buzitis J., Bolton J.L., Wigren C.A., Chan S.-L., Varanasi U., 1993, Analyses for petroleum-related contaminants in marine fish and sediments following the Gulf oil spill. Mar. Pollut. Bull. 27, 285-292.

Lin E.L.C., Cormier S.M., Torsella J.A., 1996, Fish biliary polycyclic aromatic hydrocarbon metabolites estimated by fixed-wavelength fluorescence: comparison with HPLC-fluorescent detection. Ecotoxicol. Environ. Saf. 35, 16-23.

Luthe G., Stroomberg G.J., Ariese F., Brinkman U.A.T., van Straalen N.M., 2002, Metabolism of 1-fluoropyrene and pyrene in marine flatfish and terrestrial isopods. Environ. Toxicol. Pharmacol. 12, 221-229.
Marty G.D., Hoffmann A., Okihiro M.S., Hepler K., Hanes D., 2003, Retrospective analysis: bile hydrocarbons and histopathology of demersal rockfish in Prince William Sound, Alaska, after the Exxon Valdez oil spill. Mar. Environ. Res. 56, 569-584.

McDonald SJ., Kennicutt M.C., Brooks J.M., 1992, Evidence of polycyclic aromatic hydrocarbon $(\mathrm{PAH})$ exposure in fish from the Antarctic peninsula. Mar. Pollut. Bull. 25, 313-317.

Meador J.P., 2003, Bioaccumulation of PAHs in marine invertebrates. In: Douben P.E.T. (Ed.), PAHs: An Ecotoxicological Perspective. Wiley, England, pp. 147-172.

Moore M.N., Livingstone D.R., Widdows J., 1989, Hydrocarbons in marine molluscs: Biological effects and ecological consequences. In: Varanasi U. (Ed.), Metabolism of PAH in the Aquatic Environment. CRC, Boca Raton, FL, USA, pp. 185-202.

Neff J.M., 1979, Polycyclic aromatic hydrocarbons in the aquatic environment: sources, fates and biological effects. London, Applied Sciences Publishers.

Tissot B.P., Welte D.H., 1978, Petroleum formation and occurrence. A new approach to oil and gas exploration. Springer-Verlag, Berlin Heidelberg.

van der Oost R., Beyer J., Vermeulen N.P.E., 2003, Fish bioaccumulation and biomarkers in environmental risk assessment: a review. Environ. Toxicol. Pharmacol. 13, 57-149.

Varanasi U., Stein J.E., Nishimoto M., 1989, Biotransformation and disposition of PAH in fish. In: Varanasi U. (Ed.), Metabolism of PAH in the Aquatic Environment. CRC, Boca Raton, FL, USA, pp. 93-149. 